Bradleya 30/2012

pages $25-32$

\title{
Clarifying the application of the long-confused name Aloe commutata, and the establishment of Aloe xcommutata Tod. (Asphodelaceae)
}

\author{
Estrela Figueiredo ${ }^{1}$ and Gideon F. Smith ${ }^{2}$ \\ ${ }^{1}$ Department of Botany, P.O. Box 77000, Nelson Mandela Metropolitan University, Port Elizabeth, 6031 \\ South Africa / Centre for Functional Ecology, Departamento de Ciências da Vida, Universidade de Coimbra, \\ 3001-455 Coimbra, Portugal (email: estrelafigueiredo@ hotmail.com). \\ 2 Office of the Chief Director: Biosystematics Research \& Biodiversity Collections, South African National \\ Biodiversity Institute, Private Bag X101, Pretoria, 0001 South Africa / H.G.W.J. Schweickerdt Herbarium, \\ Department of Plant Science, University of Pretoria, Pretoria, 0002 South Africa / Centre for Functional \\ Ecology, Departamento de Ciências da Vida, Universidade de Coimbra, 3001-455 Coimbra, Portugal \\ (email: g.smith@sanbi.org.za).
}

Summary: The taxonomic history and application of the long-confused name Aloe commutata Tod. is reviewed and clarified. The name had previously been variously included in the synonymy of Aloe macrocarpa Tod., A. maculata All. and A. grandidentata Salm-Dyck. We agree with Reynolds (1950) that it shows characters that are intermediate between the latter two species and is likely a hybrid between them. Given the distinct horticultural value of this hybrid, the name is here resurrected as Aloe ×commutata Tod. We also show that Engler never published a later homonym, Aloe commutata Engl.; his misapplied use of the name in a specific sense [A. commutata sensu auct. Engler (1892)], however, became entrenched in the literature.

Zusammenfassung: Die taxonomische Geschichte und Anwendung des lange fehlinterpretierten $\mathrm{Na}$ mens Aloe commutata Tod. wird analysiert und geklärt. Der Name wurde früher unteschiedlich als Synonym von Aloe macrocarpa Tod., A. maculata All. und $A$. grandidentata Salm-Dyck betrachtet. Wir stimmen mit Reynolds (1950) überein, dass das Taxon Merkmale zeigt, die zwischen den zwei letztgenannten Arten stehen, und dass es sich wahrscheinlich um die entsprechende Hybride handelt. Unter Berücksichtigung des klaren gärtnerischen Potentials dieser Hybride wird der Name hier als Aloe $\times$ commutata Tod. wieder aufgenommen. Wir zeigen zudem, dass Engler nie ein späteres Homonym Aloe commutata Engl. publizierte, aber seine fälschliche
Anwendung des Namens [A. commutata sensu auct. Engler (1892)] auf Artebene hat sich tief in die Literatur eingegraben.

\section{Introduction}

Between 1876 and 1892, Agostino Todaro (18181892) published the Hortus Botanicus Panormitanus (1876-1878; 1879-1892) in which he described, among other entities, 10 species of Aloe L., all of which were at the time grown in the Botanical Garden of Palermo, in Italy. Of the names he established, three are currently accepted as referring to good species, one represents an interspecific hybrid, and six are either of unresolved application or are treated as synonyms of other accepted names (Table 1). Two further 'Aloe' names (A. haynaldii and $A$. candelabrum) are listed by IPNI as having been published by Todaro in this book; both became established in the literature and sources of confusion (see e.g. Grace et al., 2011). However, these names in fact refer to Agave haynaldii [probably a synonym of Agave difformis A.Berger] and Agave candelabrum [probably a synonym of Agave cantala (Haw.) Roxb. ex Salm-Dyck] (see Gentry, 1982).

One of the names published by Todaro in 1878 , Aloe commutata Tod., for a maculate aloe that was cultivated in the Botanical Garden of Palermo, has become a source of confusion - it had inter alia previously been included in the synonymy of Aloe macrocarpa Tod., A. maculata All. and A. grandidentata Salm-Dyck. The history and application of the name $A$. commutata is reviewed and clarified. 

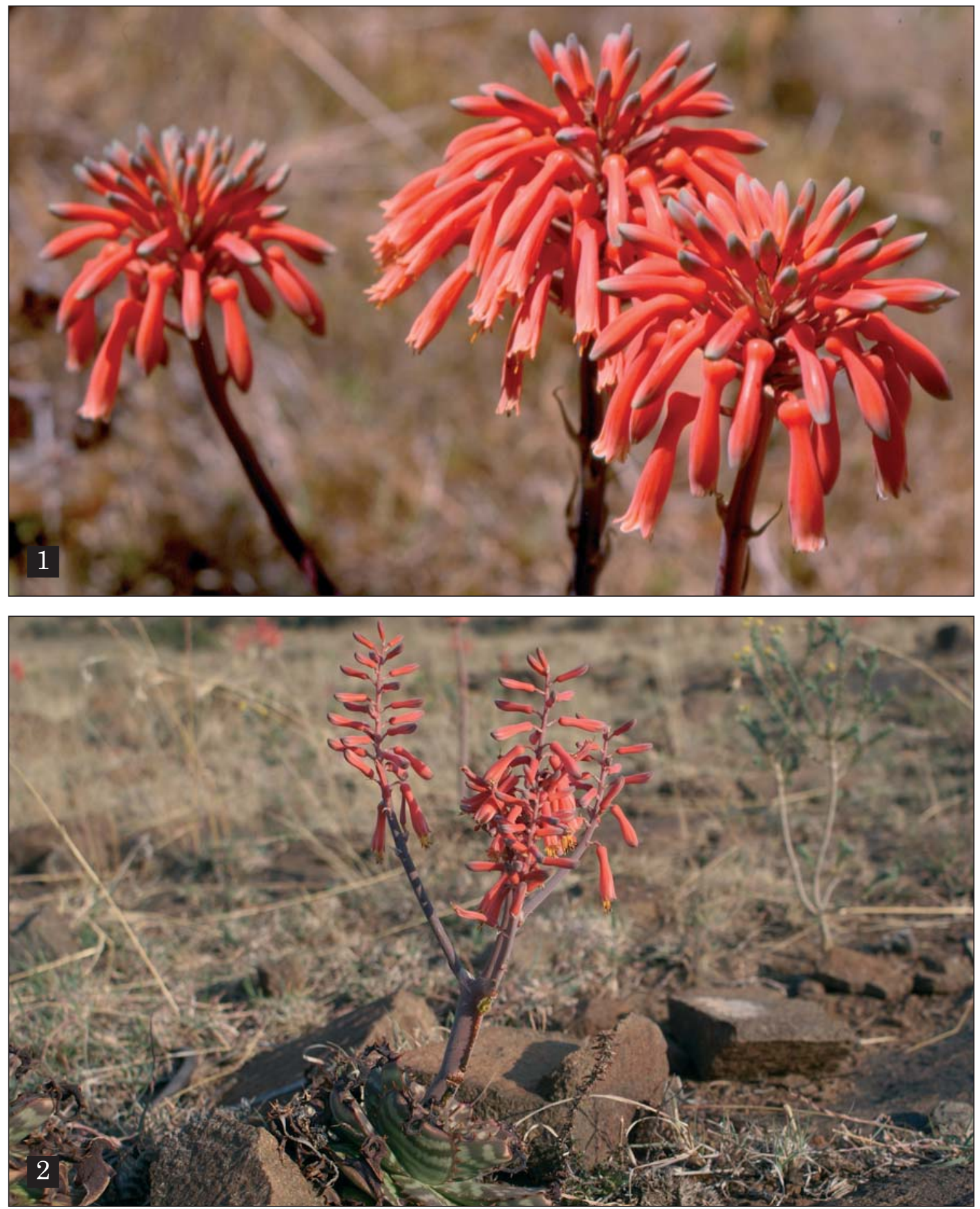

Figure 1. The flowers of $A$. maculata are longer than those of $A$. grandidentata, and have a prominent basal swelling. The flowers are usually uniformly coloured and in most forms the lower leaf surfaces are milky green rather than spotted. Figure 2. Aloe grandidentata in its natural habitat near Winburg in the Free State province, South Africa. The leaves of this species have maculations on both surfaces, and the tepals are white-margined. At this locality it occurs sympatrically with A. maculata. Photos: Gideon F. Smith. 
Table 1. Species of Aloe described by Todaro in Hortus Botanicus Panormitanus and their current status.

\begin{tabular}{|c|c|c|c|}
\hline Name & $\begin{array}{l}\text { Reference } \\
\text { (publication date*) }\end{array}$ & Origin & Status suggested in the literature \\
\hline A. agavefolia & vol. 1 , p. 85 , t. 23 (1878) & $\begin{array}{l}\text { Probably tropical } \\
\text { Africa }\end{array}$ & Application unresolved \\
\hline A. cernua & vol. 2 , p. 50, t. 36 (1890) & Madagascar & $=A$. capitata Baker var. capitata \\
\hline A. commutata & vol. 1 , p. 75 , t. 18 (1878) & $\begin{array}{l}\text { Unknown, probably } \\
\text { Cape of Good Hope }\end{array}$ & $\begin{array}{l}=\text { A. grandidentata } \text { Salm-Dyck, }= \\
\text { A. } \text { maculata All., =A. macrocarpa Tod. }\end{array}$ \\
\hline A. elegans & $\begin{array}{l}\text { vol. } 2 \text {, p. } 25 \text { (1882), t. } 29 \\
\text { (1886) }\end{array}$ & Ethiopia & Accepted \\
\hline A. fulgens & vol. 2 , p. 40, t. 33 (1889) & $\begin{array}{l}\text { Probably southern } \\
\text { Africa }\end{array}$ & $\begin{array}{l}=A \text {. arborescens Mill. subsp. } \\
\text { arborescens }\end{array}$ \\
\hline A. lanzae & $\begin{array}{l}\text { vol. } 2, \text { p. } 54 \text { (1890), t. } 39 \\
\text { (1891) }\end{array}$ & $\begin{array}{l}\text { Unknown, probably } \\
\text { Cape of Good Hope }\end{array}$ & $=A$. vera (L.) Burm.f. \\
\hline A. macrocarpa & vol. 1, p. 36, t. 9 (1876) & Ethiopia & Accepted \\
\hline A. percrassa & vol. 1, p. 81, t. 21 (1878) & Ethiopia & Accepted \\
\hline A. rossii & vol. 2 , p. 58 , t. 40 (1891) & Madagascar & $\begin{array}{l}\text { =A. deltoideodonta } \text { Baker var. } \\
\text { deltoideodonta }\end{array}$ \\
\hline A. schimperi & vol. 1 , p. 70 , t. 16 (1878) & Probably Ethiopia & $\begin{array}{l}\text { Accepted (as a hybrid between } \\
\text { A. maculata All. and } A \text {. striata Haw.) }\end{array}$ \\
\hline
\end{tabular}

*as given in TL-2 (http://tl2.idcpublishers.info/)

We agree with Reynolds (1950) that the entity to which the name was applied shows characters that are intermediate between $A$. maculata (Figure 1) and $A$. grandidentata (Figure 2 ) and is likely a hybrid between them. Given the distinct horticultural value of this hybrid, the name is here resurrected as Aloe $\times$ commutata Tod. We were able to verify that Engler did not publish a later homonym, Aloe commutata Engl.; his misapplied use of the name A. commutata Tod. in a specific sense, however, became entrenched in the literature.

\section{Aloe commutata Tod. and A. commutata sensu auct. Engler (1892)}

Aloe commutata was one of the new species described by Todaro (1876-1878). He noted that the plant to which he applied this name had previously been referred to $A$. grandidentata SalmDyck, but he considered it to be distinct as it did not have elongate-lanceolate leaves that are reflexed from the base, while the flowers were more widely spaced in the sparse inflorescences. However, he acknowledged that the perianth was clavate and the stamens exserted, which are characters associated with $A$. grandidentata. Todaro's plants were of uncertain origin, but he suggested that it might be the Cape of Good Hope, a locality name often used in older literature for (somewhere in) South Africa. In fact, the original geographical distribution ranges of the plants described by Todaro are often uncertain (see Table 1) which seemingly indicates that no accurate records were kept on their acquisition and origin

In 1897, five years after Todaro passed away, the well-known cactus and succulent specialist Alwin Berger (1871-1931) started a 17-year residency as curator of La Mortola, also known as the Hanbury Gardens, in Italy (Gastaldo \& Profumo, 1999; Greggio, 2001, 2002; Mazzino, 1997; Moore, 2004; Russo, 2001). While based there he established remarkable taxonomic insights into the classification of the genus, and the infrageneric groups he recognized were eventually adopted in an amended format by Reynolds (1950). Berger clearly had access to Todaro's material as he treated $A$. commutata in his major works on aloes (Berger, 1905, 1908). Berger $(1905,1908)$ accepted the name $A$. commutata as circumscribed by Todaro as a good species. He noted that in leaf shape and maculation the species was similar to, and could be confused with, A. saponaria (Ait.) Haw. (a name at present treated as a synonym of A. maculata All., cf. Guglielmone et al., 2009), but the shape of the perianth and the elongated racemes easily separated it from that species (Berger, 1908). Other authors did not agree with Berger's acceptance of A. commutata Tod. (Table 2.) 



Berger (1908) also referred to an A. commutata Engl., which he considered distinct from Todaro's species and synonymized with A. macrocarpa Tod. This appeared to indicate that Engler had himself described a species with the same epithet, which caused some confusion among later authors. In fact, the entity is $A$. commutata sensu auct. Engler (1892), a misapplied name. In that 1892 publication, Engler did not describe an entity as $A$. commutata under his name, but listed the species $A$. commutata Tod. and cited the collection Schimper 798 from Ethiopia. The same collection had already been cited by Baker (1881) under A. commutata Tod., which he listed as occurring in Ethiopia and noted that it was introduced into cultivation in Europe in 1878, and was again cited by Baker in 1898 under $A$. commutata Tod. Later Berger considered this collection to be wrongly identified as $A$. commutata, and determined it to be $A$. macrocarpa (Berger, 1908). He noted that it differed from A. commutata in the globose perianth base and described it as A. macrocarpa var. major A.Berger, of which it became the type.

Figure 3. Aloe $\times$ commutata in cultivation in the Desert Garden of the Huntington Botanical Gardens near Pasadena in California, USA. This hybrid has definite horticultural value. Photo: Gideon F. Smith. Figure 4. Close-up of an inflorescence of A. ×commutata, showing the club-shaped flowers. Photo: Gideon F. Smith. Figure 5. Black and white drawing of $A$. commutata (Berger, 1908: Fig. $77 \mathrm{~A}-\mathrm{D})$. This image closely coincides with the colour plate of the species included in Todaro (see Figure 6). 
Table 2. Interpretation of the name Aloe commutata Tod.

\begin{tabular}{|c|c|}
\hline Author (date: page number) & Suggested taxonomy \\
\hline Baker (1881: 165) & $\begin{array}{l}\text { Accepted, including the plant cultivated in Palermo in } 1878 \text { and the } \\
\text { Ethiopian collection Schimper } 798(\mathrm{BM})\end{array}$ \\
\hline Engler (1892: 164) & Accepted as an Ethiopian species, based on Schimper 798 \\
\hline Baker (1898: 421) & Accepted as an Ethiopian species, based on Schimper 798 \\
\hline Berger (1908: 214) & Accepted, excluding Ethiopian collections \\
\hline Groenewald (1941: 48) & Accepted, closely related to $A$. grandidentata \\
\hline Reynolds (1950: 293) & $\begin{array}{l}\text { A doubtful species that could be } A \text {. grandidentata } \times \text { A. saponaria } \\
(=\text { A. maculata })\end{array}$ \\
\hline Reynolds (1966: 94) & $\begin{array}{l}\text { Only 'A. commutata Engler non Todaro' is listed, as a synonym of } \\
\text { A. macrocarpa Tod. var. major A.Berger }\end{array}$ \\
\hline Jacobsen (1986: 153) & Accepted \\
\hline Glen \& Hardy (2000: 148) & $\begin{array}{l}\text { An insufficiently known species, probably A. maculata } \times \\
\text { A. grandidentata. }\end{array}$ \\
\hline Newton (2001: 105) & Name of unresolved application \\
\hline Govaerts \& Newton (2006) & Synonym of $A$. maculata All. \\
\hline Grace (2009: 119) & $\begin{array}{l}\text { Only 'A. commutata Engler' is listed, as a synonym of } A \text {. macrocarpa } \\
\text { Tod. }\end{array}$ \\
\hline Grace et al. $(2011: 95,181)$ & Synonym of $A$. maculata All. \\
\hline Carter et al. $(2011: 173,710)$ & $\begin{array}{l}\text { Only 'A. commutata Engler' is listed, as a synonym of } A \text {. macrocarpa } \\
\text { Tod. }\end{array}$ \\
\hline
\end{tabular}

He cited ' $A$. commutata Engler' as a synonym of this new taxon. Following this, subsequent authors also included what they referred to as 'A. commutata Engler' in A. macrocarpa (e.g. Newton, 2001; Carter et al., 2011).

Aloe commutata Tod. has been mostly cited as a doubtful or insufficiently known species (Reynolds, 1950; Glen \& Hardy, 2000; Newton, 2001), as a synonym of $A$. maculata (Govaerts \& Newton, 2006; Grace et al., 2011) or omitted (Carter et al., 2011) (see Table 2). Furthermore, Reynolds (1950) inexplicably regarded the plant depicted by Berger (1908: Fig 77 A-D; see Figure 5) as A. commutata as differing from Todaro's species in the shape of the perianth and that it could be a form of $A$. grandidentata. It is our view that these images closely coincide.

\section{Aloe macrocarpa Tod.}

The description of A. macrocarpa was also published by Todaro in 1876. According to Baker $(1881,1898)$ this species was found initially in Ethiopia and introduced in cultivation in European gardens by Schimper in 1870. Later it was found in West Africa (Keay, 1968). It is known to occur from Sudan to Benin (Demissew \& Gilbert, 1997). This species is characterized by the maculate leaves with usually numerous pale spots and longitudinal darker lines and the distinct globose swelling of the perianth. The leaves are lanceolate to lanceolate-attenuate, reaching $40 \mathrm{~cm}$ in length. While this species has large fruit, for which it was named, Aloe vanrooyenii Gideon F.Sm. \& N.R.Crouch, another maculate aloe, but from further south in KwaZulu-Natal, South Africa, easily competes with it as far as fruit size is concerned (Smith \& Crouch, 2006).

\section{Aloe tricolor Baker}

In Flora capensis, Baker (1897) recorded A. tricolor Baker as a species originating from South Africa; it was described from a living plant that flowered at Kew in April, 1877. A. tricolor, labeled as a Cape species, was described by Baker in 1877, before Todaro published his A. commutata. It was based on a plant received from the Oxford Botanic Garden, who in turn received it from a Mr Justus Corduroy of Blewbury. The name was illegitimate since there was a previous A. tricolor published in 1804 by Haworth (now a synonym of a Haworthia). Baker (1877) noted that the species differed from $A$. saponaria (=A.maculata) on the typically racemose not capitate inflorescence and constricted perianth tubes, 


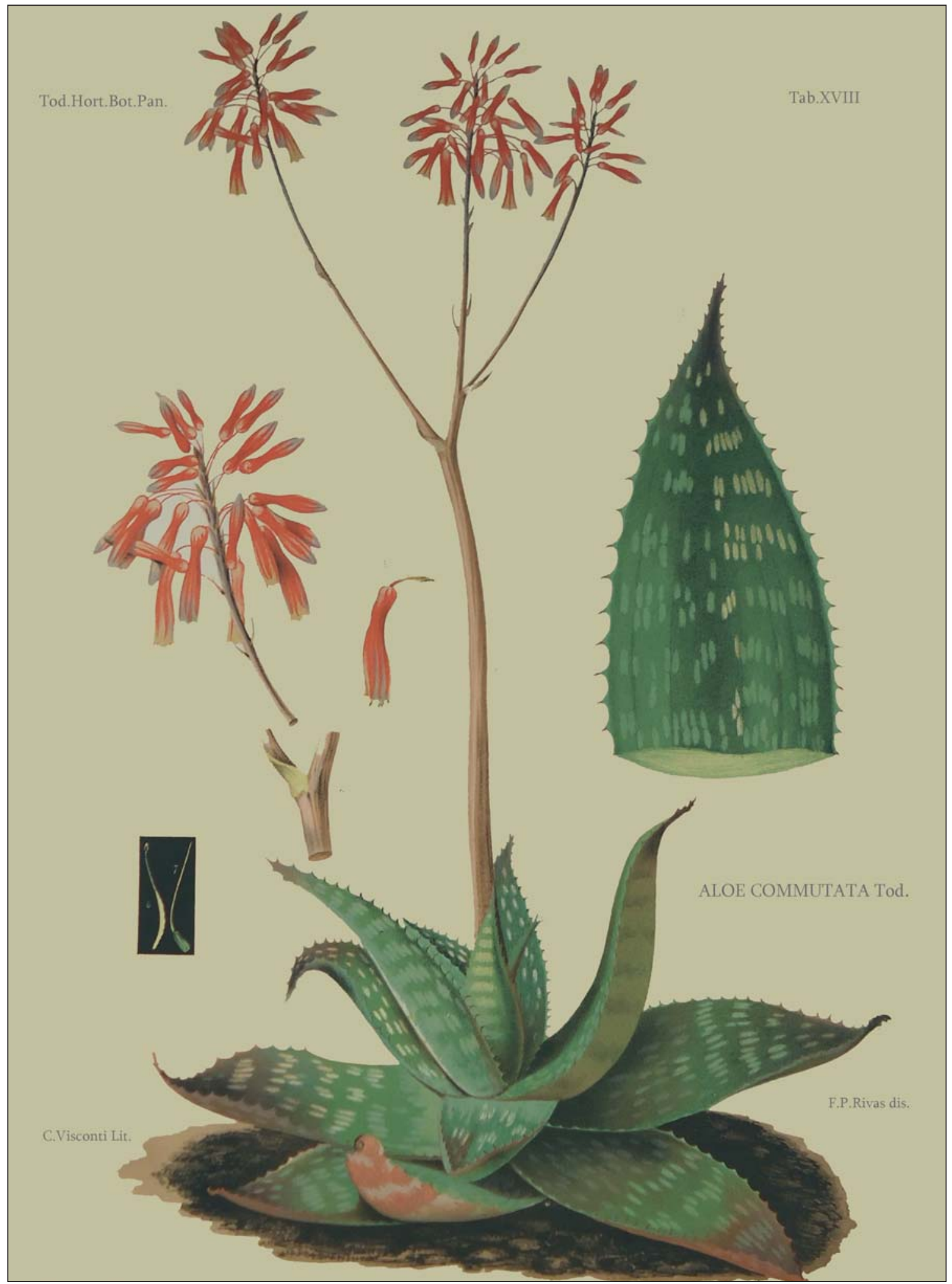

Figure 6. Colour plate of Aloe commutata (Todaro, 1876-1878: t.18). 
and from A. macrocarpa on leaf shape and maculation. According to Berger (1908) the plant described by Baker is conspecific with A. commutata Tod., and he recognised it as a variety, A. commutata var. tricolor (Baker) A.Berger. This name has been omitted in recent treatments (e.g. Carter et al., 2011) or wrongly cited as A. commutata var. bicolor (e.g. Govaerts \& Newton, 2006).

\section{Aloe commutata in cultivation}

Material of several hundred species of Aloe is today found in cultivation in the Desert Garden of the Huntington Botanical Gardens near Pasadena in California in the USA. One of these coincides closely with the description Todaro provided for A. commutata, in that the leaves are fairly short and somewhat deltoid, both surfaces are distinctly maculate, and the flowers lack the prominent bulbous swelling found in the flowers of most maculate aloes. The Desert Garden was established in 1907, at the suggestion of William Hertrich (Hertrich, 1940, 1988) who was ranch supervisor and later curator of that Garden for nearly 45 years (Houk, 1996; Lyons, 2007). Hertrich established links with Gardens around the world and it is possible that he obtained material of this Aloe from a garden such as La Mortola, near Ventimiglia in northwestern Italy, where Alwin Berger worked.

\section{Conclusion}

We conclude that $A$. commutata is distinct from A. macrocarpa and A. maculata and that it was variously synonymised with these species as a result of misinterpretations. The plant growing in England and described as A. tricolor and that growing at the same time in Palermo described as A. commutata appear to be the same entity. Both are illustrated in the literature (Todaro 18761878, tab. 18; Baker 1877: tab. 6324) and one herbarium specimen is known [s.c. s.n. (K, K000256650)]. The older name being illegitimate, the correct name for the entity is A. commutata Tod. The plant specimen referred to by Engler as A commutata belongs to A. macrocarpa, an Ethiopian/West African species. Reynolds (1950) was correct in his assessment that $A$. commutata Tod. is likely a hybrid with $A$. grandidentata as one parent. This hybrid has distinct horticultural value and appeal and we here propose its formal recognition as Aloe $\times$ commutata Tod. (Figures 3 and 4). Furthermore, at least one other interspecific hybrid in Aloe, A. ×schoenlandii Baker is known to be widely cultivated (and have become naturalized) in the USA (Holmes \& White, 2002). In instances like this it is preferable to have a hybrid name with which to refer to the entity.
Accepted nomenclature:

Aloe $\times$ commutata Tod.

A. commutata Tod. (1876-1878: 75); Berger [1908: 214, excl. cit. Baker (1881, 1898) [see Figure 5]. Type: Illustration in Todaro (1876-1878: t. 18) [see Figure 6].

A. tricolor Baker (1877: tab. 6324), nom. illeg. Type: s.c. s.n. (K, K000256650).

A. commutata var. tricolor (Baker) A.Berger (1908: 214).

\section{Aloe macrocarpa Tod.}

A. macrocarpa Tod. (1876-1878: 36). Type: Illustration in Todaro (1876-1878: t. 9).

A. commutata sensu auct. Baker (1881: 165; 1898 : 421) et Engler (1892: 164).

A. macrocarpa Tod. var. major A.Berger (1908: 210). Type: Schimper 798 (B holo-; BM iso-).

\section{Acknowledgements}

Messrs John Trager and Gary Lyons are thanked for kindly providing information on material of A. commutata grown in the Desert Garden of the Huntington Botanical Gardens. Images of Berger's black and white drawing and Todaro's colour plate of A. commutata were kindly supplied by Colin C. Walker from his personal library, but especial thanks go to Tina Wardhaugh of the Open University for her expert enhancement of these using Photoshop ${ }^{\circledR}$.

\section{References}

BAKer, J.G. (1877). Aloe tricolor. Curt. Bot. Mag. 103: t. 6324.

BAKER, J.G. (1881). A synopsis of Aloineae and Yuccoideae. J. Lin. Soc. 18: 148-240.

BAKer, J.G. (1897). Aloe. In Thiselton-Dyer, W.T., Flora Capensis 6: 302-329. L. Reeve, London.

BAKer, J.G. (1898). Aloe. In Thiselton-Dyer, W.T., Flora of tropical Africa 7: 454-469. L. Reeve, London.

Berger, A. (1905). Über die Systematische Gliederung die Gattung Aloe. Bot. Jahrb. 36: 42-68.

Berger, A. (1908). Liliaceae-AsphoideloideaeAloineae. In Engler, A. (ed.) Das Pflanzenreich, IV.38. (33), 347 pp. Verlag von Wilhelm Engelmann, Leipzig.

Carter, S., Lavranos, J.J., Newton, L.E. \& Walker, C.C. (2011). Aloes - The definitive guide. Kew Publishing/British Cactus \& Succulent Society, London.

Demissew, S. \& Gilbert, M.G. (1997). Aloaceae. In Edwards, S., Demissew, S. \& Hedberg, I. (eds) Flora of Ethiopia and Eritrea, 6, pp. 117135. Uppsala Univ. and Addis Ababa Univ., Uppsala and Addis Ababa. 
EngleR, A. (1892). Über der Hochgebirgsflora des tropischen Afrika. Abhand. König. Preuss. Akad. Wissenschf. 1891-1982, II: 1-461.

Gastaldo, P. \& Profumo, P. (1999). The Hanbury Botanic Gardens. [In the series Archives of Botanic and Garden Studies, edited by L. Aimone.] Umberto Allemandi \& C., Turin.

GENTRY, H.S. (1982). Agaves of continental North America. The University of Arizona Press, Tucson.

GLEN, H.F. \& HARDY, D.S. (2000). Aloaceae (First part): Aloe. In Germishuizen, G., Flora of southern Africa, 5, Part 1, Fascicle 1: 1-167. National Botanical Institute, Pretoria.

Govaerts, R. \& Newton, L. (2006). Aloe. World Checklist of Xanthorrhoeaceae. Facilitated by the Royal Botanic Gardens, Kew. Published on the Internet; http://apps.kew.org/wcsp/ Accessed 2011-10-18

Grace, O.M. (2009). Contributions to the systematics and biocultural value of Aloe L. (Asphodelaceae), $\mathrm{PhD}$ thesis. University of Pretoria, Pretoria.

Grace, O., Klopper, R.R., Figueiredo, E. \& Smith, G.F. (2011). The aloe names book. Strelitzia 29. South African National Biodiversity Institute, Pretoria, and Royal Botanic Gardens, Kew.

Greggio, S. (2001). Routes of discovery. French Riviera. Éditions Ouest-France.

GregGio, S. (2002). Itinéraires de découvertes. La Côte d'Azur des jardins. Éditions OuestFrance, Rennes.

Groenewald, B.H. (1941). Die aalwyne van SuidAfrika, Suidwes-Afrika, Portugees Oos-Afrika, Swaziland, Basoetoeland, en 'n spesiale ondersoek van die klassifikasie, chromosome and areale van die Aloe Maculatae. Nasionale Pers., Bloemfontein.

Guglielmone, L., Gallo, L., Meregalli, M., Smith, G.F. \& Figueiredo, E. (2009). Allioni's Aloe names (Asphodelaceae): nomenclature and typification. Bothalia 39: 177-183.

Haworth, A.H. (1804). A new arrangement of the genus Aloe, with a chronological sketch of the progressive knowledge of that genus and of other succulent plants. Trans. Linn. Soc. 7: $1-28$.

Hertrich, W. (1940). A guide to the desert plant collection in the Huntington Botanical Gardens. Henry E. Huntington Library and Art Gallery, San Marino, California.
Hertrich, W. (1988). The Huntington Botanical Gardens 1905-1949. Personal recollections of William Hertrich. The Huntington Library, San Marino, California.

Holmes, W.C. \& White, H.L. (2002). Aloaceae. In Flora of North America Editorial Committee (eds) Flora of North America north of Mexico. 26 Magnoliophyta: Liliidae: Liliales and Orchidales, pp. 410-412. Oxford University Press, New York.

Houk, W. (1996). The botanical gardens at the Huntington. Huntington Library, San Marino, California and Harry N. Abrams, Inc., New York.

Jacobsen, H. (1986). A handbook of succulent plants, 1. Blandford Press, Poole, Dorset.

KeAY, R.W.J. (1968). Aloe. In HePper, F.N., Liliaceae. In Hutchinson, J. \& DALziEL, J.M., Flora of West Tropical Africa, $2^{\text {nd }}$ edn. revised by HePper, F.N., 3, part 1, pp. 90-92. Crown Agents for Overseas Governments and Administrations, London.

Lyons, G. (2007). Desert plants. A curator's introduction to the Huntington Desert Garden. Huntington Library Press, San Marino, California.

Mazzino, F. (1997). An earthly paradise. The Hanbury Gardens at La Mortola. Sagep Libri \& Comunicazione Srl., Genoa.

Moore, A. (2004). La Mortola. In the footsteps of Thomas Hanbury. Cadogan Guides, London.

Newton, L.E. (2001). Aloe. In EgGLI, U. (ed.) Illustrated handbook of succulent plants: Monocotyledons. pp. 103-186. Springer-Verlag, Berlin.

REYNolDS, G.W. (1950). The aloes of South Africa. The Trustees, the Aloes of South Africa Book Fund, Johannesburg.

Reynolds, G.W. (1966). The aloes of Tropical Africa and Madagascar. Aloes Book Fund, Mbabane.

Russo, L. (2001). A mission in life: Thomas Hanbury and his garden at La Mortola. Bradleya 19: $67-74$.

Smith, G.F. \& Crouch, N.R. (2006). Asphodelaceae. Aloe vanrooyenii: a distinctive new maculate aloe from KwaZulu-Natal, South Africa. Bothalia 36: 73-75.

Todaro, A. (1876-1878). Hortus Botanicus Panormitanus, 1. Cyri Visconti \& Francisci Lao, Palermo.

Todaro, A. (1879-1892). Hortus Botanicus Panormitanus, 2. Cyri Visconti \& Francisci Lao, Palermo. 